\title{
Jerome Frank, Lon Fuller, and a Romantic Pragmatism
}

\author{
Charles L. Barzun*
}

Your letter of December 5 pleases me enormously, for the obvious reason that it accords with views which I have been uttering [about the difficulties of fact-finding] for some sixteen years now.

Jerome Frank, Letter to Lon Fuller, December 12, 1946'

I have not had a chance to read [your] book yet, except for the chapter on Natural Law, which I thought excellent. I am happy to see that so many pseudo-issues are gradually evaporating, and I have firmly resolved myself never to engage again in polemical writing.

Lon Fuller, Letter to Jerome Frank, October 24, 1949

\section{INTRODUCTION}

Jerome N. Frank (1889-1957) and Lon L. Fuller (1902-1978) are not frequently classed together in discussions of twentieth-century legal thought. Although they both wrote extensively about the nature of law and adjudication over roughly the same period of time (1930s-1950s), they are typically seen as standing on opposite sides of the issues that matter most in legal theory. So, for instance, when H.L.A. Hart famously characterized American jurisprudence as oscillating between two extreme views about adjudication, he explicitly mentioned Frank as one who adopted the "Nightmare" view (which sees judges as never deciding cases according to

* Armistead M. Dobie Professor of Law, University of Virginia. I would like to thank the following people for helpful discussions and comments on earlier drafts of this paper: Neil Duxbury, David Dyzenhaus, Angela Fernandez, Stef Feyen, Stephen Presser, Dan Priel, George Rutherglen, Jack Schlegel, Simon Stern, Malcolm Thorburn, Anders Walker, William Wiecek, Kenneth Winston, David Wolitz. I would also like to thank the editorial board of the Yale Journal of Law and Humanities, whose anonymous criticisms and suggestions for improvement have made this a better paper.

1. All of the letters between Frank and Fuller quoted in this essay can be found in Folder 334, Box 54 in Series IV of the Jerome New Frank papers, found at the Manuscripts and Archives of the Yale University Library. Electronic versions of all of them are on file with the author. 
law), and he may well have had Lon Fuller in mind when he spoke of the "Noble Dreamers" (who say that judges always decide cases according to law, even when the applicable legal rules are unclear). ${ }^{2}$ Writing about the same time as Hart, but drawing a slightly different distinction, Robert Summers offered Fuller's understanding of law and adjudication as a much-needed corrective to what he viewed as an "instrumental" conception of law-a conception Summers thought dominant because it included so many of the leading legal theorists of the twentieth century, including Frank. ${ }^{3}$

These depictions still appear to fit today. Frank is portrayed as an "extreme" realist, who thought judges decided cases on the basis of irrational biases. ${ }^{4}$ Meanwhile, Fuller is best known for being a critic of realism, a defender of natural law, and an influential member of the legalprocess school of legal thought, which is itself seen as a response to precisely those excesses of realism that Frank is said to epitomize. ${ }^{S}$

But these classifications are misleading and incomplete. They are misleading because they seem to license inferences about the views of these thinkers that are not supported by what they actually wrote. Realism is associated with an enthusiasm for the use of the social sciences in studying law that Frank did not share. ${ }^{6}$ And legal-process theory is said to involve a turn to procedure with the thought that doing so absolves judges and legal scholars of the need to make substantive judgments of value, ${ }^{7}$ whereas Fuller emphasized repeatedly the inescapability of making value judgments in all intellectual activities.

The classifications are incomplete because they fail to capture the

2. H.L.A. Hart, American Jurisprudence through English Eyes: The Nightmare and the Noble Dream, in ESSAYS IN JURISPRUDENCE AND PHILOSOPHY 128, 132 (1983) [hereinafter "Nightmare"].

3. Robert S. Summers, Professor Fuller's Jurisprudence and America's Dominant Philosophy of Law, 92 HARV. L. REV. 433, 434 (1978).

4. See Hart, Nightmare, supra note 2, at 128 (describing Frank's views and then observing that Oliver Wendell Holmes "never went to these extremes"); see also Rodger D. Citron, The Nuremburg Trials and American Jurisprudence: The Decline of Legal Realism, the Revival of Natural Law, and the Development of Legal Process Theory, $2006 \mathrm{MICH}$. ST. L. REV. 385, 391 ('[Frank's] views made him an extreme - and extremely clear-spoken - legal realist.").

5. JOHN HENRY SCHLEgel, AMERICAN LEGal REALISM AND EMPIRICAL SOCIAL SCIENCE 6 (1995) (characterizing Fuller, along with Roscoe Pound, Morris Cohen, and John Dickinson as the more prominent and influential critics of realism); see also NEIL DUXBURY, PATTERNS OF AMERICAN JURISPRUDENCE 232 (1995). For the view that process theory amounted to a response to, or taming of, realism, see, for example, MORTON J. HORWITZ, THE TRANSFORMATION OF AMERICAN LAW 18701960: THE CRISIS OF LEGAL ORTHODOXY 254 (1992) (observing that Legal Process theorists sought to "absorb and temper the insights of Legal Realism after the triumph of the New Deal").

6. See G. Edward White, From Realism to Critical Legal Studies, 58 VA. L. REV. 999, 1014 (1972) (observing that "[i]n the early years of the twentieth century the focus shifted to the so-called 'social sciences': statistics, ethnology, economics, sociology," and linking that development to the rise of legal realism). But see Charles Barzun, Jerome Frank and the Modern Mind, 58 BUFF. L. REV. 1127 (2010) (interpreting Frank's realism as "humanistic" and influenced by the pragmatism of William James).

7. See laura Kalman, The Strange Career of Legal Liberalism 36 (1996) (explaining that process theorists attempted "to separate law from politics, process from substance, fact from values"); Gary Peller, Neutral Principles in the 1950's, 21 U. MiCH. J.L. REFORM 561, 590 (1988) (observing that for legal-process theorists "in the realm of procedure, neutral, value-free reasoning was possible"). 
common intellectual threads that link the thought of the two thinkers. As the quotations that introduce this Article indicate, Frank and Fuller corresponded for several years in the 1940s and 1950s, and each seems to have found in the other a kindred spirit on matters related to the philosophy, practice, and teaching of law. That they did so is not particularly surprising if one looks carefully at their published work. There one sees that they shared similar philosophical assumptions about the nature of knowledge, which led them to take similar views about how judges do and should decide cases. Specifically, both thinkers were convinced that our perceptions of the world and our judgments about how to act within it were indelibly shaped by our own emotions, purposes, intuitions or motives (for short, I will sometimes call them "motives"8). For this reason, both thought that sound adjudication required judges to attend to their own intuitive reactions to the facts of cases before them and to articulate as best they could how those reactions supplied grounds for their decision - even though perfect articulation of such grounds was often not possible. In other words, deciding cases properly required judges not only to take in knowledge of the external world, but also to improve their own self-awareness by engaging in a process of introspection.

These common threads justify characterizing Frank and Fuller as members of what I call a romantic pragmatist strand of legal thought. Theirs was a pragmatic view of adjudication because it viewed law in instrumental terms and assessed the correctness of judicial decisions according to how well they are validated by experience. But it was romantic because it held that the relevant "experience" for testing and guiding judicial decisionmaking - and practical reasoning more generally - should include judges' own emotional responses to the facts of the cases before them. ${ }^{9}$

The romantic form of legal pragmatism may be contrasted with a

8. I do so because this term strikes me as occupying a midpoint between "emotions" (which connotes irrationality) and "purposes" (which connotes a certain practical rationality). The burden of my essay is to show that although Frank used the former word more, and Fuller the latter, the intended meanings are actually not so far apart. My hope is that using this more neutral word makes that point clearer.

9. See infra, pp. 129-133 (elaborating on this meaning of pragmatism). Here I use the term "romanticism" in a semi-technical sense. I mean to indicate in a general way this view's intellectual connection to the literary and philosophical movement of the late eighteenth and early nineteenth centuries by emphasizing the epistemic value it accords the emotions, particularly those triggered by particular experiences. See The Romantic Period: The Nature of Romanticism, ENCYCLOPEDIA BRITANNICA ("The most notable feature of the poetry of the time is the new role of individual thought and personal feeling. Where the main trend of 18 th-century poetics had been to praise the general, ... the Romantics found the source of poetry in the particular, unique experience."), available at https://www.britannica.com/art/English-literature/The-Romantic-period. However, I do not mean for my interpretation of Frank or Fuller to depend on any strong or controversial claims about the nature, or most important elements, of the romantic movement as an historical and cultural phenomenon. If I am wrong about that - if the account of romanticism offered below differs from what the reader considers the best or consensus understanding of that movement - I am happy to have my account treated as idiosyncratic. My main concern here is with understanding twentieth-century legal theory, not literary romanticism. 
technocratic one. This view also sees legal concepts as instruments for sound judicial decisionmaking, but it more narrowly defines the relevant validating experience to include only the social, political or economic consequences of a decision. Whereas the technocratic pragmatist takes certain goals (or ends or values) as fixed and asks only whether a decision one way or another helps meet that goal, the romantic pragmatist considers the question of what the proper goal (or end or value) is to be itself part of the object of inquiry.

Why bother labeling Frank and Fuller in this way? Almost every legal thinker of the last century could plausibly classified as "pragmatist" in one way or another, and yet this distinction enables us to distinguish among different sorts of pragmatists in a way that has both historical and contemporary relevance. ${ }^{10}$ As an historical matter, the romantic/technocratic dichotomy cuts across the realist/legal-process divide and so offers us a new way of understanding mid-twentieth century legal thought. ${ }^{11}$ As I show below, during both the heyday of realism in the 1930s and during the postwar period when legal process dominated the scene, one finds both sorts of pragmatism at work.

Moreover, the core distinction endures into the present day. Take, for example, Judge Richard A. Posner and former Justice David Souter. Both of those judges see themselves as part of a pragmatist tradition, but they interpret that tradition in quite different ways. ${ }^{12}$ For Posner it means mostly that judges should take into account the economic and practical consequences of their decisions, whereas for Souter it means, at least in part, that they should reflect on how their own views have been shaped by the social and political context in which they live. ${ }^{13}$ Both views are

10. See Robert Summers, InSTRUMEntalism AND AMERICAN Legal Theory (1982); Frederick Schauer, The Limited Domain of the Law, 90 VA. L. REV. 1909, 1927 (2004) (referring to the "pragmatic and instrumentalist core of twentieth-century American legal thought").

11. As I note in Part 1II, this distinction follows one that Ken Winston has drawn in an effort to distinguish Fuller's work from other instrumentalist theories. See Kenneth I. Winston, Is/Ought Redux: The Pragmatist Context of Lon Fuller's Conception of Law, 8 OXFORD J. LEGAL STUD. 329, 345 (1988). It also further develops Professor Duxbury's critique of the conventional view that legalprocess theory was a "response" to realism. DUXBURY, supra note 5, at 205.

12. See Richard POSNER, LaW PRAGMATISM, AND DEMOCRACY (2005) ("For some years now ... I have been arguing that pragmatism is the American judicial ethos and also the best guide to the improvement of judicial performance," and then setting out to clarify what he means by "pragmatism"); David Souter, Interview (Constitution Day, 2009) (describing what he means by pragmatism and then explaining that such a view is "essential to my kind of judgment"), available at http://www.c-span.org/video/?288993-2/former-justice-souter-constitution.

13. Compare Richard A. Posner, The Jurisprudence of Skepticism, 86 MICH. L. REV. 827, 863 (1988) (arguing that a judge deciding an antitrust suit should first extract from legal materials an overall goal, such as wealth maximization, and should then, "having made that choice," look to the relevant legal precedent before making a "a policy judgment (in some cases it might approximate a logical deduction) resolving the case in accordance with the principles of wealth maximization") with David Souter, Conference on the Humanities in Civil Society (2009) (min. 25:00) ("In all sorts of ways, later judges see things that earlier judges did not see. Or they deal with facts that were not faced in earlier adjudication. To explain these kinds of cases fully a person has to know what it is that changes judicial perception from one age to another. It may be differing individual experiences, but more likely it is differences in the experience of the broader society over time. What an appellate judge perceives depends on the common experience which he assimilates and brings with him to the 
plausible interpretations of the pragmatist tradition, but they point to quite different understandings of the nature of the judicial task. Posner instructs the judge to look outward and to the future in order to achieve the best policy outcome; Souter asks the judge to look inward and to history in order to ensure that she is properly fulfilling her judicial duty. Souter's pragmatism is of the romantic sort.

This Article is primarily concerned with defending the first, historical thesis. It aims to bring out the similarities between the views of Frank and Fuller in order to reveal their common views on the nature of human knowledge and of judicial decisionmaking. Part II begins that effort by showing how the themes mentioned above can be found in their earliest work. Since these themes are commonly associated with legal realism, Part III seeks to clarify the sense in which Frank was a realist and Fuller a critic of realism. Part IV then shows how over the next few decades Frank and Fuller each developed these themes in different ways and for slightly different purposes. But the common philosophical vision remains, and it can be seen clearly by contrasting their views with a contemporaneous one advanced by a pair of scholars under the name "policy science." Part V then elaborates and defends my suggestion that Frank and Fuller may profitably be seen as part of a romantic pragmatist tradition of law. It does so by first spelling out in a bit more detail what I mean by each of the terms in that description. It then explains why characterizing these midcentury thinkers in that way matters for both the history and philosophy of law.

\section{THE EARLY WORKS: SOME COMMON THEMES}

It seems to me that you have said in some of your earlier writings in effect that facts are important because they are subjective. Factfinding and fact-interpretation represent a hole in the judicial process through which subjectivity and personal predilection enter.... Now I don't for a moment deny either the truth or the importance of this assertion. It needed to be made.

Lon Fuller, Letter to Jerome Frank, Jan. 9, 1947

Several times during the past few years, I have meant to ask you why you don't publish in book form your admirable early paper on legal fictions. I try to tell the Yale students a bit about the subject - largely ignored in most law-schools - and wish I could refer them to your job in readily accessible form.

Jerome Frank, Letter to Lon Fuller, July 8, 1954

bench. And herein lies the problem. For judges are not very good at explaining this background or at explaining how their common background is different from their predecessors."), available at http://www.c-span.org/video/?284498-1/humanities-civil-society. 
Each of the authors under examination made one of his earliest and yet most lasting intellectual contributions in the year 1930. In that year, Frank, then a corporate lawyer from Chicago, published Law and the Modern Mind, which fell "like a bomb on the legal world." 14 And Fuller, still a professor at Duke University, published the first of his now-classic series of articles on legal fictions. ${ }^{15}$ Although in some ways the two works seem to take on different issues and point in opposite directions, in them one can find common assumptions and goals, which both authors would continue to develop and expand upon.

\section{A. Law and the Modern Mind}

Frank's book is mainly about the problems of fact-finding, and it amounts to an attack on the rationality of adjudication. More specifically, it is a polemic against the common belief (or at least what Frank took to be a common belief) ${ }^{16}$ that the law is certain - a belief Frank calls the Basic Myth. For Frank, the Basic Myth was a problem because it wrongly ignored the way in which errors in fact-finding made it impossible to predict how legal rules would be applied in any particular case. When judges or juries evaluated evidence, especially the credibility of witnesses, their judgments were frequently skewed by personal, idiosyncratic biases and prejudices. ${ }^{17}$ But such errors had deeper roots in the intrinsic features of the human mind. Drawing on the work of the German philosopher Hans Vaihinger, Frank emphasized that our thought could never be "in complete correspondence with factual reality." 18 Rather, the way we conceptualize experience and hence perceive the world is colored by our own motives and emotions. For Frank, then, the myth to be overcome was not just a belief in legal certainty, but the belief that we can ever have certain knowledge of anything.

Frank famously (or notoriously) attributed people's (including judges') belief in certainty - and in particular, certainty in law - to their inability to outgrow the emotional need they had as children for an authoritative father-figure who would provide them with comfort and security. ${ }^{19}$ The solution was therefore for judges to recognize the role that these emotions and longings play in their own reasoning and to learn to relish, rather than

14. Jerome Frank, LAW ANd the Modern Mind (1930); Charles E. Clark, Jerome N. Frank, 66 YALE L.J. 817 (1957).

15. L.L. Fuller, Legal Fictions: Part I, 25 ILL. L. REV. 363 (1930); Legal Fictions: Part II, 25 ILL. L. REV. 513 (1930); Legal Fictions: Part III, 25 ILL. L. REV. 877 (1930).

16. See Brian Z. TAMANAHA, Beyond THE Formalist-REAlist Divide: THE Role of Politics IN JUDGING (2009) (arguing that many of the skeptical views about law and adjudication associated with legal realism had long before been accepted by judges and legal theorists).

17. Id. at $\mathbf{1 1 5}$ (observing that a judge's "own past may have created plus or minus reactions to women, or blond women, or men with beards, or Southerners, or Italians, or Englishmen, or plumbers or ministers, or college graduates, or Democrats").

18. Jerome Frank, Law AND the MOdern Mind 173 (1949 ed.).

19. Frank repeatedly emphasized that his was a "partial explanation." See, e.g., id. at 14 ("Chapter II: A Partial Explanation"). 
fear, the epistemic uncertainty that such a recognition entails. Judges who could develop such self-awareness possessed what he called the "scientific spirit" or the "modern mind" of the book's title. ${ }^{20}$ It was a mind "free of childish emotional drags, a mature mind."21

\section{B. Legal Fictions}

Fuller's series of articles conducts a study of fictions that purports to burnish the credentials of-rather than challenge-traditional commonlaw methods of reasoning. Fuller set out to explain what fictions were and what motivated their use in the law, and then to evaluate whether or when fictions should be preserved or discarded. Fuller defined a fiction as "(1) a statement propounded with a complete or partial consciousness of its falsity, or (2) a false statement recognized as having utility." ${ }^{22} \mathrm{He}$ suggested various possible explanations for their use, but the most important one was one he called "intellectual conservatism." This label described circumstances in which a judge used a fiction "merely because he does not know how else to state and explain the new principle he is applying." ${ }^{23}$ In such a circumstance, rather than saying, "[f]or reasons which are essentially inarticulate and not wholly understood even by myself, I decide for the plaintiff," the judge instead might say, for instance, that a defendant must be "deemed to have invited" a child onto the land. ${ }^{24}$

Fuller, like Frank, drew on the work of Hans Vaihinger, who had argued in his book, The Philosophy of 'As if,' that fictions-concepts which were known to be false-were an essential feature of any form of intellectual inquiry. What Vaihinger's work showed, Fuller explained, was that to talk of fictions as being "false" was actually misleading because doing so wrongly assumed the existence of an external reality by reference to which we could judge these concepts to be untrue. In fact, our minds were "instruments for enabling us to deal with [the] world."25 They thus altered reality in perceiving it. And that was true of all systematized forms of knowledge. Thus, as long as they were used with proper recognition of their fictional quality, fictions were a "sign of good mental digestion; it indicates the vigor and capacity of our minds." 26

\section{Common Themes: Fictions and Science}

Each of these works, though different in style and tone, reflects common goals and assumptions. Frank hoped judges' increasing awareness of their

\footnotetext{
20. Id. at 268 .

21. Id.

22. Fuller, Fictions I, supra note 15 at 369.

23. Fuller, Fictions II, supra note, 15 at 524.

24. Id. at 527 .

25. Id. at 885 .

26. Id. at 886 .
} 
own biases and emotions would make them better judges and would enable law to become a "portion of the science of human nature."27 Meanwhile, Fuller understood the value of fictions to lie in their capacity to enable judges to achieve results they intuitively thought just but for reasons they could not quite express articulately. More than that, the scientific value of fictions, for Fuller, depended on a kind of judicial selfconsciousness. After all, if a judge came to actually believe the fiction he invoked or invented - rather than just seeing it as a way to vindicate his inchoate intuitions of justice-it became, in Fuller's view, a harmful dogma. ${ }^{28}$

Frank and Fuller also offered nearly identical explanations for why the natural sciences had seemed to enjoy more intellectual progress than legal science. Fuller insisted that most of the motivations for legal fictions he discussed had clear analogues in the social and natural sciences. ${ }^{29}$ But he conceded that one motive for their use had no analogue in science: "What I have called previously the fictions of emotional conservatism and of policy and apologetic and merciful fictions proceed from stresses in the judicial mind which, although probably not wholly unknown to the scientist, are nevertheless not an important factor in his mental life." 30 That motive of "emotional conservatism" was one born of a "longing for a feeling of conservatism and certainty."

That longing for certainty was precisely what Frank had argued handicapped legal thinking. When he took up the question of what explains why lawyers and judges, but not (most) scientists, were plagued by this psychological need for security, Frank dismissed concept-worship, or "scholasticism," as an explanation (for that was a symptom, not a cause), instead concluding that it was the subject matter of law that triggered these longings for security in a way that the less emotionally charged objects of natural-scientific inquiry failed to do. ${ }^{32}$ Like Fuller, then, Frank distinguished between law and science by reference to the human motives and purposes law activated, rather than by drawing a metaphysical dichotomy between the domain of facts and that of value.

Finally, Frank and Fuller both characterized formal doctrine as in some sense "fictional." Fuller saw judges as constantly applying the old and inherited concepts and categories to new situations in order to achieve justice in the cases before them. The result was that those concepts slowly changed meaning. That process was constant and ongoing, and it was only

27. FRANK, MODERN MIND (1949), supra note 18, at 158.

28. Fuller, Fictions I, supra note 15, at 370 (“A fiction taken seriously, i.e., 'believed', becomes dangerous and loses its utility.").

29. Fuller, Fictions $I I$, supra note 15 at 905 (arguing that such legal concepts as rights, duties, powers, and liabilities are "devices through which we organize and simplify our subject matter, and correspond to such notions as 'energy,' 'matter,' and 'the force of gravity' in physics").

30. Id. at 906 (emphasis added).

31. Fuller, Fictions $I I$, supra note 15 at 520 .

32. FRANK, MODERN MIND (1949), supra note 18, at 98-99. 
when that process of conceptual change seemed crude - when there was a felt gap between the concept and the phenomenon to which judges were trying to apply the concept - that we dub a concept a "fiction." ${ }^{\prime 33}$ Similarly, Frank encouraged judges to see all law, insofar as it was constituted by general statements, as fictitious and so properly used merely as an instrument for achieving justice in the particular case. ${ }^{34}$

\section{LEGAL REALISM AND LEGAL INSTRUMENTALISM}

With much of your criticism of Llewellyn and Moore in your Pennsylvania Law Review article I concur. Llewellyn and I have disagreed since we first met - because he blinds his eyes to the trial courts. Much the same is true of Moore.

Jerome Frank, Letter to Lon Fuller, April 17, 1947

I am sorry if my passing reference to the Realists in my article on Jurisprudence has caused misapprehension. . . I want to come back to the point soon, and when I do I shall try to do fuller justice to variations among the Realists, which your new introduction to Modern Mind has done much to clarify.

Lon Fuller, Letter to Jerome Frank, Oct. 24, 1949

That these early works contain similar themes is not surprising since they are themes commonly associated with legal realism, which was reaching its peak around that time. Still, Fuller is known as an early critic of legal realism. ${ }^{35}$ So the discussion above prompts at least two questions. First, in what way was Fuller a critic of realism and in what way was he sympathetic to its aims and aspirations? Second, to the extent that he was critical of realism, was Frank's version of realism his target?

\section{A. Fuller as Realist and Critic}

Fuller endorsed some aspects of realism. Most important was the view that the law as practiced frequently deviated from formal doctrine. The very existence of legal fictions was itself evidence of the gap between the language of the formal law and the results judges sought to achieve. If there were no felt disconnect between the result the judge hoped to secure and what the literal application of the relevant rules would seem to entail, then, according to Fuller, there would be no need for fictions. ${ }^{36}$

Fuller further agreed with the realists that the sorts of non-technical considerations that actually explain judicial practice sometimes justify it

33. Fuller, Fictions $I I$, supra note 15 at 525.

34. FRANK, MODERN MIND (1949), supra note 18, at 179.

35. See DUXBURY, supra note 5, at 223 ("Fuller was both a critic and an advocate of realist legal thought.").

36. Fuller, Fictions $I I$, supra note 15 at 514-15. 
as well. In an early article, entitled "American Legal Realism," he wrote that "[o]ne of the chief services of the realist school has been to enlarge the field of the legally relevant and to invest 'extra-legal' considerations with a species of respectability. ${ }^{37} \mathrm{He}$ even thought that the cause of legal certainty - the value traditionally prized by legal scholars - was best served by attending more carefully to such non-technical considerations. ${ }^{38}$ He observed, for instance, that he could sometimes generate greater consensus among his law students as to how to resolve some particular hypothetical dispute if he told them to ignore the law on the topic than if he told them to apply it. The reason was that if he told them to apply the law some of his students would struggle to find a creative legal rationale to achieve the result that they all agreed was the just or fair one, while others would apply the formal law irrespective of the apparent injustice of the result. ${ }^{39}$

Finally, and as a consequence of the first two points, Fuller conceived of the legal scholar's role as in part that of clarifying and improving legal doctrine by identifying and tracing out the practical purposes that actually motivated courts to decide cases the way they did, rather than by deducing results from the "nature" of particular concepts. He subsequently characterized his article on legal fictions as such an effort, ${ }^{40}$ and his twopart article on the role of reliance interest in contract law-now considered a legal-realist classic- constituted a similar project. ${ }^{41}$

In what sense, then, was Fuller a critic of legal realism? ${ }^{42}$ Four main criticisms stand out in his work. The first was his concern that the healthy suspicion of conceptualism, which he endorsed (and in service of which he conceived his own article on legal fictions), had been taken too far. Sometimes characterized as "nominalism," the mistake, according to Fuller, was to assume that only concrete tangible things mattered for the purposes of law. He insisted, to the contrary, that "not all significant facts are 'concrete.",43

Fuller made a related criticism of the realists' aim to use only empirical methods to study the law. Many realists sought to distinguish clearly between factual descriptions, on the one hand, and "value judgments," on

37. L.L. Fuller, American Legal Realism, 82 U. PA. L. REV. 429, 434 (1934).

38. Id. at 436 .

39. Id. at 436 .

40. Id. at 443 n. 31 .

41. L.L. Fuller \& William R. Perdue, Jr., The Reliance Interest in Contract Damages: 1, 46 YALE L.J. 52 (1936), The Reliance Interest in Contract Damages: 2, 46 YALE L.J. (1937) (arguing that courts often allow plaintiffs who have relied on promises to recover more often than the formal law would seem to allow and suggesting that the doctrine would be improved by more articulately recognizing such reliance as a legitimate basis for recovery).

42. Cf. Myres S. McDougal, Fuller vs. The American Legal Realists: An Intervention, 50 YalE L.J. 827 (1941). Fuller took up, and criticized realism primarily in his article, "American Legal Realism," supra note 38 , though there he focuses narrowly on two realist works by, respectively, Karl Llewellyn and Underhill Moore, and in his first book, THE LAW IN QUEST OF ITSELF 46-65 (1940).

43. Fuller, American Legal Realism, supra note 37, at 447. 
the other. ${ }^{44}$ But Fuller thought that attempts to describe purposive human action, whether that of judges or anyone else, in terms of pure "behavior" resulted in poor descriptions. He thus criticized Underhill Moore's "institutional" approach for its failure even to attempt to understand what the bankers whom he was studying (for an analysis of banking law) were trying to accomplish when engaging in the activities he described.$^{45}$ One cannot properly understand what is going on in some institutional context, Fuller insisted, unless you understand why the individuals under examination are taking the actions they are.

Third, Fuller criticized some realists for insufficiently appreciating the value of legal certainty. With Frank clearly in mind, Fuller treated dismissively the idea that a desire for certainty was "evidence of a childish petulance, unworthy of the twentieth century mind." $46 \mathrm{He}$ expressed the same attitude toward Frank's suggestion that "the really enlightened and normal person takes a "positive delight in the hazardous, incalculable character of life." "47 To the contrary, Fuller thought that the realists themselves had suggested useful ways in which the law could be made more certain.

The fourth and final criticism Fuller leveled against the realists was the same one he leveled against John Austin and John Chipman Gray. He took the realists to be endorsing a form of legal positivism, which insisted on distinguishing clearly between the law as it is and the law as it ought to $b e .{ }^{48}$ Fuller's quarrel with legal positivism was that it was not a productive or useful way for the lawyer or judge to think about the law. Judges deciding cases at common law were often struggling (and failing) to articulate adequately the true motives and purposes for their decisions (hence the need for legal fictions, as we've seen). But the legal realist who studied only the "behavior" of judges did not recognize such motives as part of the law since they were only (unobservable) aspirations of law as it "ought to be." Fuller's concern was that by refusing to consider such aspirations to be the "law," legal positivists (including legal realists) directed the attention of lawyers, judges, and scholars away from the motives which should properly serve as the law's guide for reform and growth. He thus emphasized that he "did not care how realism defines words" but instead was "concerned with the way it directs the application of human energies in the law." 49

44. See, e.g., Karl Lewellyn, A Realistic Jurisprudence-The Next Step, 30 CoLUM. L. REV. 431, 445 (1930) (arguing that the "behavior approach" for which he was advocating "ceases to promise objective agreement" once it begins talking of the "interests" law protects "except in this - that isolation of the value judgement [sic], in presentation, from the observed phenomena on which it in part rests, would clarify much discussion").

45. Fuller, American Legal Realism, supra note 37, at 455.

46. Id. at 431 .

47. Id. at 433 (quoting FrANK, MODERN MiND (1930), supra note 14, at 17).

48. FULLER, QUEST, supra note 42 at 55.

49. Id. at 60 . 


\section{B. Frank as Realist and Critic}

Which, if any, of Fuller's criticisms apply to Frank? The answer is that most do not but that some do. First, as to anti-conceptualism. Frank, like other realists, criticized the "scholasticism" of traditional legal thinkers, by which he meant the tendency to ascribe undue significance to abstract concepts. ${ }^{50}$ Tellingly, though, in Law and the Modern Mind he argued that a "scholastic" obsession with concepts was not the most important cause of the false belief in legal certainty. Such an explanation was too conclusory. The problem for Frank was not the reliance upon concepts and abstractions as such; it was the false belief that those concepts and abstractions corresponded to some "reality." Following Vaihinger, Frank thus encouraged judges and lawyers to treat doctrinal concepts instead as fictions, as tools suited for particular purposes. ${ }^{51}$

Nor did Frank embrace the strict empiricist methodology that was Fuller's target. To the contrary, he repeatedly emphasized the limits of empirical methods. In his later work, Frank became increasingly critical of what he perceived to be the deterministic - or, as he put it, "fatalistic"assumptions on which many social and natural sciences were predicated. ${ }^{52}$ Like Fuller, he denied the reality of "pure" facts. "A fact," Frank insisted, "reflects, or results from, a human motive, interest, or purpose, in dealing with experience." 53 Facts were "human achievements, inventions, human feats. ${ }^{.54}$ Even in Law and the Modern Mind, Frank made clear he thought the search for scientific certainty was as misguided as the search for legal certainty. ${ }^{55}$

On the question of the value of legal certainty, the issue is closer. As we have seen, Fuller took particular aim at Frank's suggestion that the quest for legal certainty represented a childish impulse. Furthermore, Fuller looked for and valued in the law, more than did Frank, uniformities and regularities. ${ }^{56}$ Even here, though, the differences are less stark than they first appear. For the certainty Fuller longed for was one secured not by rigid application of formal rules but instead by more faithful attention to the purposes and values of the law. Hence the consensus he found among his students, noted above, on what result common sense or basic fairness

50. FRANK, MODERN MIND (1949), supra note 18, at 69-70. Frank later changed his view on scholastic philosophy and apologized for his earlier critique. See Jerome Frank, Legal Thinking in Three Dimensions, 1 SYRACUSE L. REV. 9, 18 (1949) (observing that his "reference in [Law and the Modern Mind] to 'scholasticism' were superficial and unfair").

51. Id. at 179.

52. JEROME FRANK, FATE AND FREEDOM 87 (Rev. ed., 1953).

53. Jerome Frank, The Place of the Expert in a Democratic Society 8 (Speech to the Brandeis Lawyers' Society, 1944).

54. Id.

55. FRANK, MODERN MIND, supra note 18 , at 307.

56. Cf. id. at 105 (arguing that the "spirit of the creative scientist" is one which "yearns not for safety but risk" and which "devotes itself to new ways of manipulating protean particulars and not to the quest of undeviating universals"). 
would require in the hypothetical case he posed to them. ${ }^{57}$ Frank made a very similar point, suggesting that certainty in a "deeper sense" would result if judges "are the more enlightened, the more quick to detect and hold in check their own prejudices, the more alive to the fact that rules and precedents are not their masters but merely agencies to be utilized in the interest of doing justice." $\$ 88$

Fuller's final criticism, of the legal positivism implicit in legal realism, also applies in part, but only in part, to Frank's brand of realism. On the one hand, throughout his career, Frank argued that exposing the "realities" of court practice - particularly trial-court practice - would stimulate legal reform, rather than hinder it. ${ }^{59} \mathrm{He}$ thus embraced Holmes's view that the proper focus of lawyers, judges and legal scholars should be on what courts "do in fact," rather than what we wish they did. ${ }^{60}$ On the other hand, like Fuller, he sought to focus attention on the actual motives of courts, and those included the "oughts" for which judges strive. "What the law ought to be constitutes, rightfully, no small part of the thinking of lawyers and judges," Frank explained. The key was to make such thinking conscious, rather than unconscious. ${ }^{61}$

\section{Two Kinds of Instrumentalism}

We can now see some points of intersection between the ideas of Fuller, the "critic" of realism and those of Frank, the "extreme" realist. Like other realists, they both conceived of law in instrumental terms. That is, they denied that legal concepts mapped onto objective features of the world; rather, legal rules and concepts were best understood as tools courts use to achieve certain goals. And like other realists, they thought legal practice and theory could be improved by loosening the constraints the formal law imposed on courts.

But here is where Frank and Fuller went in a different direction than others did. Some realists sought to bracket off (at least temporarily) the question of what ends courts should be pursuing and to focus instead primarily on the empirical question of whether, and if so, how effectively, courts were in fact achieving those ends. Karl Llewellyn, for instance, implored scholars to scrutinize more carefully the "interests" that law

57. Fuller, American Legal Realism, supra note 37 at 436 . Frank made the same point by comparing two states whose formal criminal laws formally treated recklessness very differently, with one allowing it to serve as a mens rea sufficient to establish what were only considered purposeful crimes in the other state. Frank then showed how the punishments actually issued by judges made the sanctions for similar crimes functionally comparable in the two states. FRANK, MODERN MIND (1949), supra note 19 , at $109-10$.

58. FRANK, MODERN MIND (1949), supra note 18, at 134.

59. Frank emphasized this point in a letter to Fuller in 1947: "[B]eginning with the first stuff I wrote on "jurisprudence" (Law and the Modern Mind) to date, I have been eager to dissipate the myths about court-house doings, because I have felt that only a correct description of those doings would help to bring about their needed reform." Letter to Lon Fuller, April 17, 1947.

60. FRANK, MODERN MIND (1949), supra note 18, at 134.

61. Id. at 181 . 
purported to serve and to examine whether what judges do actually serves those interests. He sought a "comparison of facts with facts," he explained; that is, "objective data, the specific data, claimed to represent an interest, compared with the actual doings of the judges and the actual effects of their doings on the data claimed to represent an interest." ${ }^{.62}$ Similarly, Felix Cohen endorsed a "functional" approach to studying law, which required scholars to "look behind the pretty array of 'correct' cases to the actual facts of judicial behavior," and to use "statistical methods in the scientific description and prediction of judicial behavior." ${ }^{963}$ As Professor Summers explains, for such scholars, "law serves simply as means to external goals," ${ }^{\prime 64}$ so the important question was whether it was serving those goals effectively. As we'll see, this sort of instrumentalism persisted in a less skeptical vein into the 1940s and 1950s in form of "policy science." 65

Neither Frank nor Fuller embraced that sort of instrumentalism, however; nor did they advocate the use of empirical methods that such a goal seemed to require. Instead, their instrumentalism was more global. As Professor Kenneth Winston has said, Fuller's instrumentalism is "a thesis about the practical nature of cognition." $"$ The same is true of Frank. The lesson they both drew from Vaihinger was that even the concepts used in the natural and social sciences should be understood as tools used to achieve certain purposes rather than as descriptions of reality. ${ }^{67}$ Thus, neither were as "enamored with the scientific method" 68 as were other realists, and each concerned himself (albeit in quite different ways) with questions that empirical methods could not resolve - questions about judicial purposes and goals themselves, about what motivates courts to render decisions.

Still, that Frank and Fuller shared areas of concern and criticized the

62. KarL N. Llewellyn, JURISPRUDENCE: REALISM IN TheORY AND PRACTICE, 446 (1962). I should note, however, that elsewhere, Llewellyn took an approach more similar to that of Frank and Fuller. See Dan Priel \& Charles Barzun, Legal Realism and Natural Law, in LAW, THEORY AND HISTORY: NEW ESSAYS ON A NEGLECTED TOPIC (Maksymilian Del Mar \& Michael Lobban eds., forthcoming 2017).

63. Felix Cohen, Transcendental Nonsense and the Functional Approach, 35 COLUM. L. REV. 809,833 (1935).

64. SUMmERS, supra note 10 , at 435 . Although they all "agreed that at least means could be reasoned about," Summers explains, they denied that one could reason about the ends of law. Id. at 437. Such interests or ends of law were simply taken for granted as given. Thus, for them "the problems of social ordering are divisible into two distinct stages: setting goals, and then devising means to achieve them." Id. at 438 .

65. See infra, Section V.A.

66. Winston, supra note 11 , at 341 (distinguishing such a thesis, which he ascribes to Fuller and whose roots he finds in the thought of William James and John Dewey, from "a superficial instrumentalism," which "conceives of the forms of legal order simply as artifacts fabricated for the attainment of independently given ends").

67. Cf. Fuller, Fictions III, supra note 15, at 879 ("Where Ihering taught German lawyers to think of legal rules in terms of purpose, Vaihinger is teaching them to regard legal thinking itself as a means to an end.").

68. SUMMERS, supra note 10 , at 442 . 
methods of social science is insufficient to establish an important connection between their views. For what we want to know is why they thought an empiricist approach inadequate for legal theory. Was the reason the same for each of them? And if so, how could that shared rationale have motivated their otherwise seemingly so different intellectual ambitions?

We already know part of the answer. Frank and Fuller shared a philosophical view, which they found in both Vaihinger and in the American pragmatists, according to which the mind does not act as a mirror to the world but instead acts upon it and does so for certain purposes. ${ }^{69}$ But that shared philosophical premise cannot alone explain their more mature accounts of law or adjudication because it is possible to draw deeply skeptical conclusions from such a premise. If it is impossible to observe pure "facts" about the world, then it would seem we have reason to distrust all knowledge claims and view them instead as merely the product of political, economic, social, racial, ideological, or simply arbitrary interests, and hence irrational (or at least epistemically unjustified) ${ }^{70}$ And yet neither Frank nor Fuller drew such skeptical conclusions. So inquiring into why neither did so will allow us to fill out and make more concrete their distinctive brand of American legal instrumentalism.

\section{THE SELF AS SOURCE OF MYSTERY AND VALUE}

The law review boys asked me to read your "Say it with Music." I found it stimulating and delightful. Throughout it reveals a rare combination of wisdom and sensitivity. So far as any alleged "ideological" differences in our viewpoints are concerned, I find nothing in it to quarrel with.

Lon Fuller, Letter to Jerome Frank, March 26, 1948

I want to comment on some of your recent important comments in [your review of] Patterson's book... Your emphasis on the means aspect of the means end relation is eminently desirable. It will indeed, expand "the area of workable agreement."

Jerome Frank, Letter to Lon Fuller, July 8, 1954

Such an inquiry begins by identifying the premise on which the skeptical conclusion just mentioned depends. The conclusion depends on the assumption that the human motives which provide the criteria for

69. See Winston, supra note 11 (arguing, based on his reading of Fuller's private papers, that the dominant philosophical influence on Fuller's thought was the pragmatism of William James and John Dewey).

70. This is, of course, precisely the kind of conclusion some have interpreted "postmodernists" as endorsing. Whether that allegation is a fair one is a question beyond the scope of this paper. 
selecting and organizing phenomena and so converting it into "knowledge" are not themselves capable of evaluation according to criteria of better and worse. But that is precisely the premise that Fuller and Frank both rejected. Both thought that the emotions, impulses, purposes, and motives that constitute the human self were (a) mysterious, difficult to identify, and sometimes impossible to fully articulate but (b) a source of genuine moral insight, at least under some conditions. It is the combination of these two views of the human self that helps explain why Frank and Fuller may be seen as part of a Romantic tradition of legal thought that traditional dichotomies fail to capture.

\section{A. Frank, Faith and Freedom}

Throughout his career, Frank emphasized that the human self was constituted by a variety of motives for an individual's actions and beliefs that often remained obscure to the individual him or herself. We see this view in Law and the Modern Mind in both his explanation of why the Basic Myth (of legal certainty) is false and of why, despite its falsity, it prevails among laypersons and judges. Frank argued that the law was uncertain because when judges interpreted the law or made factual findings they were beset by biases and prejudices of which they were mostly unaware. At the same time, the myth in law's certainty endured because people had failed to outgrow the need for the emotional security they felt as children and so unconsciously sought a "father-figure" in the law.

Frank did not pursue the particular father-figure theory much beyond his book, but his focus on the self as full of partially conscious and unconscious motives remained a constant theme in his writing. In fact, he even voiced skepticism about the existence of a single "self" at all, criticizing the tendency of some modern psychologists to insist upon the need for an "integrated self." For Frank "[t]he over-integrated man-like Hitler-is a totalitarian ideal." selves, and they are never unified, at one," so we should think of an individual as a "democracy of selves," containing dissent, inconsistency and even "anarchy" in its organization. ${ }^{72}$

Frank also continued to insist that the drives and motives that constitute these various selves often remained opaque even to the person who possessed them. He repeatedly praised Holmes, for instance, for having recognized the importance of such unconscious motives. ${ }^{73}$ Idiosyncratic

71. JEROME Frank, COURTS ON TRIAL 404 (1949).

72. Id.

73. See, e.g., Jerome Frank, Mr. Justice Holmes and Non-Euclidean Thinking, 17 CORNELL L. Q. 568, 571 n.6 (1931) ("'Every important principle which is developed by litigation is in fact and at bottom the result of more or less definitely understood views of public policy; most generally, to be sure, under our practice and traditions, the unconscious result of instinctive preferences and inarticulate convictions." (quoting OLIVER WENDELL HOLMES, THE COMMON LAW 35-36 (1881)); 
unconscious prejudices often explained why judges and juries believed some witnesses rather than others, Frank asserted, but it was impossible to control such biases through the use of legal rules. ${ }^{74}$

But Frank did not think that all such motives for decisions were irrational. Given the attention he devoted in Law and the Modern Mind to the biases and prejudices, the "plus and minus reactions," that plague judicial fact-finding, and given the psychological neuroses that he thought explained the desire for legal certainty, one might think that Frank was pessimistic about the epistemic value of a judge's moral intuitions about, or emotional reactions to, a set of facts. But such was not the case. Even in that book, Frank expressed confidence in the wisdom of the judicial

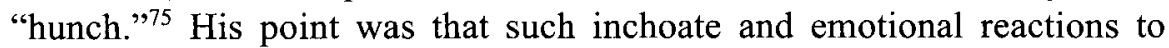
particular facts needed to be brought out and made more visible, rather than distorted and frustrated by strict legal rules. We needed judges, he explained, "with a touch in them of the qualities which make poets, who will administer justice as an art." We should therefore "encourage, not discountenance, imagination, intuition, insight." $" 76$

This idea that adjudication was ultimately about achieving justice and that justice was an art is a theme that Frank continued to develop and emphasize. In one of his most oft-cited articles, "Words and Music," he compared a judge's task when interpreting a statute to that of a performer, who must interpret a composer's artistic purpose. "A judge with an imaginative personality," Frank explained, "supplies 'an increment of vitality that is ... desirable ... and truly necessary in order to put' the legislative "message across." 77

A year later, in "Say it with Music," Frank extended the analogy between art and judging by comparing the possibilities for, and obstacles to, effective criticism of trial-court findings of fact to those of art criticism. ${ }^{78}$ As with the work of an artist, the problem for understanding and evaluating a judge's fact-finding, Frank argued, was that the mental processes by which a judge believes some witnesses rather than others is mysterious, not only to critics but often to the judge himself. Frank thus

Jerome Frank, Cardozo and the Upper-Court Myth, 13 LAW \& CONTEMP. PROBS. 369, 370 (1948) (observing that "Holmes, too, had frequently noted that sometimes subconscious factors affected judges, that they sometimes decided cases intuitionally, that policy attitudes, too often entertained unconsciously, influenced decisions").

74. Jerome Frank, Both Ends Against the Middle, 100 U. PA. L. REV. 20, 24 (1951) (arguing that the "the unconscious prejudices of trial judges or jurors for or against particular witnesses, or litigants, or lawyers" are impossible to control through procedural rules); Jerome Frank, Modern and Ancient Legal Pragmatism-John Dewey \& Co. vs. Aristotle: I, 25 NOTRE DAME L. Rev.. 207, 231 (1950) (observing that procedural rules are ineffective at controlling "the unconscious prejudices of trial judges or jurors for or against witnesses, or litigants or lawyers").

75. FRANK, MODERN MIND, supra note 18 , at 111.

76. Id. at 181 .

77. Jerome Frank, Words and Music: Some Remarks on Statutory Interpretation, 47 COL. L. REV. 1259,1264 (1947).

78. Jerome Frank, Say it with Music, 61 HARV. L. REV. 921 (1948). 
endorsed the advice Lord Mansfield supposedly gave to a new trial judge "that he should give his decisions omitting his reasons, since his decisions would probably be right but his reasons almost surely wrong." "79

The reason the grounds for decisions lingered in obscurity was that judges did not reach such judgments through a process of "reasoning"; instead, they appeared to the judge at once, and as a whole. Frank drew this lesson from the work of Gestalt psychologists, who had emphasized the way in which the mind perceived phenomena in shapes or wholes directly, rather than as the combination of parts. "The gestaltist's favorite illustration," Frank observed, "is a melody: a melody does not result from the summation of its parts; thus to analyze a melody is to destroy it." $\$ 80$ Indeed, the true explanation for why a judge makes such judgments is in some sense beyond the reach of language itself. ${ }^{81}$ Thus, for a judge to articulate adequately his response to conflicting testimony, "he would be obliged-as a once popular song put it — to 'say it with music." "82

None of this implied that criticism of trial-court judgments, or reforms of trial practices, was impossible. To the contrary, Frank wrote at length about the need for such reforms. ${ }^{83}$ He thought the process of writing opinions, for instance, encouraged clear thinking, so he recommended that courts be required to articulate, to the extent possible, their reasons for their factual findings. ${ }^{84} \mathrm{He}$ also suggested trials be filmed, so that one would have some basis for criticizing a judge's credibility judgments, which often depended on interpreting a witness's demeanor. ${ }^{85}$ But the reforms for which he advocated most were (1) efforts to make both substantive and procedural law more flexible so as to allow courts to make individualized judgments in a more honest and open way ${ }^{86}$; and (2) the better training of trial judges (and juries), which would include education as to the power of their own "biases and prejudices." ${ }^{17}$ Both of these latter two reforms depend on an assumption that, when given proper scope, and cultivated in the right way, a judge should trust his or her inchoate intuitions about what justice requires in the particular case. The question then is, on what metaphysical and epistemological grounds, if any, did Frank justify such an optimistic assumption about human intuitions?

One possible answer is natural law. ${ }^{88}$ For Frank not only embraced the

79. Id. at 926 .

80. Id. at 929 .

81. Id. at 932 (arguing that a judge's "decisional process, like the artistic process, involves feelings that words cannot ensnare").

82. Id. at 933 .

83. See, e.g., FRANK, COURTS ON TRIAL, supra note 71.

84. Frank, Say it with Music, supra note 78, at 949-50.

85. Id. at 955 (citing Frank's opinion in Skidmore v. Baltimore \& Ohio R. R., 167 F.2d 54 (2d 1948).

86. Id. at 953 .

87. Id. at 955 .

88. See FRANK, FATE AND FREEDOM, supra note 52, at 113-43; FRANK, COURTS ON TRIAL, supra 
tenets of natural law but endorsed Fuller's particular articulation of it, quarrelling only with Fuller's use of the term "natural law" itself, which he thought inferior to the simpler "justice." ${ }^{89}$ But that answer won't do because Frank repeatedly emphasized that, even though there were a few moral principles that applied to all of humanity, those principles were too abstract to be of aid to the judge adjudicating any particular case. ${ }^{90}$ Furthermore, even if such principles provided "objective" criteria for criticizing legal rules or their application, they were not particularly helpful for the trial judge trying to figure out which witnesses to believe. ${ }^{91}$

A better answer is that Frank thought that providing satisfying answers to such metaphysical and epistemological questions was impossible. This answer should hardly surprise since one of Frank's main points in Law and the Modern Mind was that we can never have certain knowledge of "reality" (whether moral or physical) and that we must therefore learn to live in a perpetual state of "painful suspension," in which we make decisions even while recognizing the personal nature of the motives that lay behind our judgments. ${ }^{92}$ Doing so was exceedingly difficult because of the mind's natural inclination toward stability and certainty. Only those with a "mature mind," infused with the "scientific spirit," had the courage to maintain their convictions in the face of such uncertainty.

But the terms in which Frank described this attitude changed over time. Whereas in his earlier work, he talked of the courage necessary to live in a state of "painful suspension," in his later work, he described the same attitude as a kind of faith. ${ }^{93}$ In his 1945 book, Fate and Freedom, for instance, Frank endorsed William James's idea of a "faith ladder," according to which one reasons from the possibility of some metaphysical picture being true, to the "fitness" of it being true, to the conclusion that it "shall be true." $" 94$ Indeed, it was on this basis that Frank justified a belief in

note 71 , at $346-74$. For a discussion of Frank's views on natural law, see Priel \& Barzun, supra note 62.

89. FRANK, FATE AND FREEDOM, supra note 52, at 296.

90. See FrANK, COURTS ON TRIAL, supra note 71 , at 356 ("That there are a few uniformities among men, of all times and climes, cannot be doubted. But they are minimal. Above the very few basic human needs and characteristics are others of amazing flexibility and variety.").

91. Frank, Say it with Music, supra note 78, at 940; Jerome Frank, Modern and Ancient Legal Pragmatism -John Dewey \& Co. vs. Aristotle: II, 25 NOTRE DAME L. REV. 460, 503 (1950) ("Presumably there is such acceptance [of natural law] in Spain and South Ireland; yet no one suggests that, in those lands, specific court decisions are more predictable and just, less subject to avoidable mistakes of trial court 'fact-finding' and litigation-uncertainty, than in the United States.").

92. FRANK, MODERN MIND, supra note 18 , at 172-82.

93. Compare id. at 19 ("Most men do not achieve, as [William] James did, the courage to tolerate much less enjoy, the idea of ultimate and irreducible contingency.") with FRANK, FATE AND FREEDOM, supra note 52 , at 16 (arguing that the idea that "[M]en's conscious and deliberate purposes" can shape the future is a thesis "which can neither be proved nor be disproved scientifically but which is a matter of faith"). On the connection between faith and courage, see generally PAUL TILLICH, THE COURAGE TO BE (1952). See, e.g., id. at 189 ("The Lutheran courage returns but not supported by the faith in a judging and forgiving God. It returns in terms of the absolute faith which says Yes although there is no special power that conquers guilt. The courage to take the anxiety of meaninglessness upon oneself is the boundary line up to which the courage to be can go.").

94. FRANK, FATE AND FREEDOM, supra note 52, at 169. 
objective moral principles. "If ideals which some men regard as noble are realized, they will become natural. Man does not find his 'oughts' spelled out for him in nature: he puts them there."95

The most important metaphysical position Frank used such a "faith ladder" to climb towards was the affirmation of human free will. According to Frank, since one cannot refute the existence of free will on the basis of empirical evidence, we need not, and therefore, should not, deny its existence. Revealingly, Frank said he preferred the term "possibilism" to "free will" because the latter term suggested man's agency was based in pure emotion or will, whereas in fact it should be better understood as a free form of "intelligence." "Whatever the precise term, Frank devoted much of Fate and Freedom to a defense of human freedom and to an attack on what he perceived to be its threats. Chief among these was the deterministic assumption of the natural and social sciences. "Scientific fatalism is but a faith, a dismal and cruel one," Frank lamented. But he insisted that "[w]e need not accept it" because "[ $t]$ here is no reason why we should forsake the American faith-which rests on the facts of daily experience - that human purposes are real." $" 97$

\section{B. Fuller, Purpose, and Natural Law}

Fuller did not emphasize as much as Frank did the role that irrational biases and prejudices might play in fact-finding or legal interpretation. ${ }^{98}$ Nevertheless, he agreed with Frank that the true reason for a judge's decision might well remain obscure to himself. Like Frank, he thought such motives could serve as a useful guide for legal decisionmaking. Beginning with his book, The Law in Quest of Itself, Fuller used the notion of human purposes to ground a theory of natural law. ${ }^{99}$

In that book and in later articles Fuller argued that natural law began with recognition of the difficulty of divorcing the "is" from the "ought" when trying to understand human actions and institutions. ${ }^{100}$ His argument for this view consisted in the following line of reasoning: All human activity is necessarily purposive activity. In order to understand or describe a person's activities, even if only for the sake of prediction, the observer must discern the purpose of the person's actions and make a judgment about whether that purpose has been achieved. But since making such a judgment depends on an assumption about what counts as success in achieving that purpose, the judgment is an essentially evaluative one.

\footnotetext{
95. Id. at 141 .

96. Id. at 145 .

97. Id. at 105 .

98. Though as we have seen, he did not ignore them entirely. See Fuller, Fictions $I I$, supra note 15 , at 519 (discussing "emotional conservatism").

99. See FULLER, QUEST, supra note 42; Lon Fuller, Human Purpose and Natural Law, 3 NAT. L. F. 68 (1958); Lon L. Fuller, A Rejoinder to Professor Nagel, 3 NAT. L.F. 83 (1958).

100. FULLER, QUEST, supra note 42, at 11-14; Fuller, Human Purpose, supra note 99, at 68-72.
} 
Therefore, understanding or describing human activity requires evaluation. ${ }^{101}$

One question this argument immediately raises is why determining a subject's purpose requires an evaluative judgment rather than simply a description of the individual's mental state, namely his intention to take some action for some goal. There were two parts to Fuller's answer to this challenge. The first was to deny that having such a purpose was equivalent to having a conscious intention. Often we have an intention without ever giving explicit conscious thought to that intention. To illustrate this point, Fuller quoted Wittgenstein: "Someone says to me: 'Show the children a game.' I teach them gaming with dice, and the other says, 'I didn't mean that sort of game.' Must the exclusion of the game with dice have come before his mind when he gave me the order?" 102 To Fuller the answer was obviously no.

Fuller made the same point in his Contacts casebook. There he observed that the schools of psychology influenced by Freud had "performed a great service by dramatizing the fact that the determinants of human conduct are not to be identified with consciousness." They had shown, rather, that "many acts are performed in quest of goals of which the actor is himself completely ignorant." 103 Thus, the problem of how to understand the nature of such goals or intentions, according to Fuller, "lies somewhere between the superficial layer of consciousness and the dark inner recesses of the human psyche probed by the psychoanalysts." 104

The second part of Fuller's response was to suggest that even if such unconscious motives were discoverable, they would rarely point to a single purpose. In one example he offered, he imagined watching a boy pressing a knife against a clam. We are confused about what the boy is doing until we understand that he is trying to open the clam. ${ }^{105}$ So that is one purpose. But why is the boy trying to open the clam? To eat it? Or to learn about mollusks? The answer we provide will determine what we think of his actions when he then drops the clam and starts running toward an aquarium. In particular, it will determine whether we think the boy has radically altered his goal or found a more effective means to achieve his existing goal. ${ }^{106}$

Fuller thought that this example illustrated the way that human actions were directed not to a single purpose but to a "congeries of related purposes." ${ }^{107}$ Thus, in order to understand the boy's actions, Fuller insisted that one must understand the boy's true purposes, and that requires

101. Fuller, Human Purpose, supra note 99, at 68-71.

102. Id.

103. LON FULLER, BASICS OF CONTRACT LAW 668 (1947).

104. Id.

105. Fuller, Human Purpose, supra note 99, at 69.

106. Id. at 71 .

107. Id. 
making a judgment about the ultimate purposes of human life. "If I understand what the boy is doing," Fuller explained, "it is because of our shared human nature, a nature that in both of us is at all times incomplete and in process of development." 108

Fuller's thought was that the common law could be seen as a similar sort of process in which judges make reference to shared purposes in order to understand what their predecessors were up to. Fuller called this process a "collaborative articulation of shared purposes," in which each judge made an effort to get at what earlier judges were in some sense trying to say, but did not or could not because such ends or purposes were "not stirred into active consciousness [of the previous court] by the facts of the case being decided." 109 Under this view, when there was a line of cases developing one particular doctrine, we could plausibly say that the facts of the later cases enabled subsequent judges to "see more truly what they were all trying to do from the beginning." 110

Under this view, the formal law was never in perfect conformity with the purposes or motives behind it because it was never possible to discover with certainty what those purposes were. Indeed, it was never even possible to determine whether any given goal was truly the end sought after or instead simply a means to achieve some further end. Crucially, though, one selected an end in part by assessing the means available to achieve it. So, for instance, Fuller argued in a 1954 book review that one could not determine whether "euthanasia should be legalized without first considering the social manageability of the task of selecting the right people to put to death." and ends open for a reciprocal adjustment with respect to each problem." 112

That law required the constant evaluation of both ends and means, each in light of the other, meant that law was always in the midst of an adjustment or, as Fuller would sometimes put it, in the process of "becoming." He thus once explained why he took so seriously his students' moral intuitions about cases discussed in class: "If we apply the term "law'," he explained, "to that which is coming to be, then the conclusion of an oncoming generation of lawyers may be 'law' in a more real sense than the dictum of some eighteenth-century English judge that happens to be embalmed in a casebook." ${ }^{\prime 13}$ Fuller thought that the best interpretation of the natural-law tradition consisted of efforts to articulate and justify something like that process of "becoming," even if it had often

108. Id.

109. Id. at 74 .

110. Fuller, Rejoinder, supra note 99, at 98.

111. Lon Fuller, American Legal Philosophy at Mid-Century, A Review of Edwin W. Patterson's Jurisprudence, Men and Ideas, 6 J. LEG. EDUC. 457, 479 (1954).

112. Id.

113. Lon L. Fuller, On Teaching Law, 3 STAN. L. REV. 35, 41 (1950). 
done so "clumsily."114

There are many possible objections to this line of reasoning, but two particularly glaring ones were leveled against Fuller. His responses to them are revealing. The first objection denied the plausibility of the view that judges had "latent" purposes that other judges could subsequently discover. ${ }^{115}$ To this Fuller responded that the existence of such latent purposes seemed to him a common truth of psychology, confirmed by ordinary experience. ${ }^{116} \mathrm{He}$ suggested that we become aware of such purposes in situations when, perhaps in a moment of crisis, a friend may "help us to understand what we really want." 17 The same idea is implicit in legal education and practice. He rhetorically asked why courts and law professors use hypothetical fact-patterns to test a legal rule if not on the assumption that doing so could help bring into consciousness ideas about ends, purposes, and values, which we possess in some sense but of which we are only dimly aware. ${ }^{118}$

The second objection was that even if such latent purposes do exist, that fact does not cause a "blurring of fact and value," let alone warrant an inference to the existence of natural law. Common-law judges could all be engaged in a collaborative articulation of shared evil purposes. ${ }^{119}$ Put another way, there's a difference between (a) the descriptive claim that a person has some purpose or end in view (or only partially in view or even totally out of view) and (b) the evaluative claim that such a purpose or end is good or worthy of pursuit. To some, Fuller's failure to recognize this distinction evidenced a deep philosophical confusion, if not intentional obfuscation. $^{120}$

Fuller recognized this objection, though he never seemed quite satisfied with any answer to it. At times, he seemed tempted to reply by resorting to a more traditional natural-law view, resting on an explicitly teleological

114. Fuller, Human Purpose, supra note 99, at 73.

115. See Ernest Nagel, On the Fusion of Fact and Value: A Reply to Professor Reply to Fuller, 3 NAT. L.F. 77, 81 (1958) ("An end-in-view that is nevertheless not explicitly present in active consciousness seems to me just a myth, the product of the same type of dubious reasoning which assumes that the outcome of a complex series of changes can be explained only by postulating the outcome as already 'implicitly present' in the initial terms of the series.")

116. Fuller, Rejoinder, supra note 99, at 96 (saying that he conceived of the existence of such purposes as "being an almost obvious truth of psychology").

117. Fuller, Human Purpose, supra note 99, at 73.

118. Fuller, Rejoinder, supra 99, at 99.

119. See, e.g., H.L.A. Hart, Positivism and the Separation of Law and Morals, 71 HARV. L. REV. 593,629 (1958) (observing that "there may be just the same sense that a new case will implement and articulate the purpose of a rule in interpreting the rules of a game or some hideously immoral code of oppression whose immorality is appreciated by those called in to interpret it").

120. See, e.g., Morris Cohen, Should Legal Thought Abandon Clear Distinctions?: Review of The Law in Quest of Itself, by Lon Fuller, 36 LLL. L. REV. 239, 245-46 (1941) (arguing that "the fact that the ought and the is are mixed in our dark view... is no reason against unmixing them in order to clarify things and remove some of the darkness" and concluding that "[d]espite Professor Fuller's professed rejection of mysticism from jurisprudence ... it is difficult to see how he can deny a definite strain of irrationalism, if not obscurantism, in his distrust of clear ideas and of factual scientific inquiry generally"). 
understanding of human nature. "The whole man, taken in the round, is an enormously complicated set of interrelated and interacting purposes," Fuller asserted in the same book review earlier mentioned. "This system of purposes constitutes his nature, and it is to this nature that natural law looks in seeking a standard for passing ethical judgments. That is good which advances man's nature; that is bad which keeps him from realizing it." 21 In the same article, he cited the political philosopher Leo Strauss as someone who had come to a similar understanding of natural law. ${ }^{122}$

But Fuller never developed much further this teleological understanding of human nature. He seemed reluctant to commit himself to any understanding of human beings that would strike many as inconsistent with modern science, explicitly distancing himself from religious understandings of natural law. Yet he never explained how ethical principles could be derived from a purely naturalistic or scientific understanding of human nature. In the same book review, he suggested that psychoanalysis, though seemingly remote from traditional natural law, was also premised on the idea that man needs to be "straightened out" and yet had resources within himself to do such straightening. ${ }^{123}$ But he did not attempt to justify that premise, except to say that "if the psychoanalyst does not do something roughly equivalent to helping his patient realize his 'true nature,' then his whole profession loses intelligible meaning."124

In the end, then, Fuller's faith in the reality or intelligibility of discerning true or universal human purposes amounted to a not-very-well articulated article of faith. His attitude is perhaps best conveyed in a letter he wrote to his friend and interlocutor, H.L.A. Hart, in response to Hart's review of Fuller's book, The Morality of Law. Hart had concluded his review by observing that Fuller "has all his life been in love with the notion of purpose and this passion, like any other, can both inspire and blind a man. I have tried to show how it has done both to the author."125 About this passage Fuller wrote to Hart:

All I can say of Miss Purpose is that the Old Girl still looks good to me. One of her enduring charms is that she is a very complex creature indeed, subject to unpredictable moods of surrender and withdrawal. I believe deeply in her without pretending that I really understand her. So the high romance of which you complain will probably continue despite your thoughtful warning that our liaison promises trouble. ${ }^{126}$

121. Lon Fuller, Philosophy at Mid-Century, supra note 111, at 472.

122. Id. at 471 n. 26 .

123. Id. at 473 .

124. Id.

125. H.L.A. Hart, Book Review: Lon Fuller, The Morality of Law, 78 HARV. L. REV. 1281, 1296 (1965).

126. Letter to H.L.A. Hart, February 3, 1965 (Lon Fuller Papers, Box 3, Folder 14). 


\section{Common Themes: Faith and Human Purpose}

Summing up, Frank and Fuller both understood all knowledge to depend on human motives, but neither drew deeply skeptical conclusions from the fact of such dependence. Instead, they both thought that some motives were better than others for the purpose of theoretical and practical decisionmaking and, in particular, for the purpose of judicial decisionmaking. Furthermore, both thought that ensuring that a judge's intuitive reactions to a particular set of facts reflected good purposes (moral principles or wise policies) rather than bad ones (or personal biases) required the judge to engage in careful introspection.

This line of reasoning invites a demand for justification: Why think that such intuitions put judges on the right track when making decisions? Fuller and Frank responded to this demand in somewhat different ways. Fuller suggested that there might be common, perhaps even universal, human purposes, which judges intuit by virtue of being either part of the community or simply by being human. He thus looked for, and thought he could find, regularities or patterns in social life, not just in terms of behavior, but in terms of common purposes, needs, and values. The common law offered one example of judges inquiring into such common purposes, the pursuit of which he thought amounted to a form of natural law. Hence, law as human purpose and "becoming."

But if Fuller sought uniformities and commonalities in human nature, Frank celebrated man's uniqueness and the value of diversity. He chafed at the use of the term "natural law" because it suggested that man's nature was fixed and determined. For the same reason he rejected what he took to be the assumptions and implications of various social sciences, instead arguing that each individual was unique and free and that social progress was neither inevitable nor impossible. One must strive for it. Although Frank recognized the existence of a few universal moral principles, he insisted that they were too abstract to be of help to the individual facing a particular decision, such as a judge deciding a case. In such circumstances, the judge had only his intuitions and judgments about the facts before him. And though he could never be certain that his motive to secure justice was not being distorted by passion or prejudice, better to have faith in one's own intuitions of justice than to try to eliminate or constrain them through the use of rigid substantive or procedural rules. Hence, law as the personality of the judge.

In fact, though, even in explaining their faith in human intuitions and emotions, the two approaches circle back on one another. Frank did ultimately endorse parts of the natural-law tradition, objecting primarily to the term itself, rather than to what he took to be its core claim, which was that there are broad moral principles applicable to all people at all times. At the same time, Fuller's endorsement of natural law is probably best understood as the result of his own effort to climb James's "faith ladder" in just the way Frank endorsed. Fuller began Law in Quest of Itself, the 
book in which he first defended a natural-law view, by describing his conception of legal philosophy as a "pragmatic" one, whose purpose was "to give a profitable and satisfying direction to the application of human energies in the law" and to ask what effect one's words might have on law students, lawyers and judges. ${ }^{127}$ It thus seems likely that he saw his own effort to develop a theory of natural law as justified primarily by how it might affect the way judges and lawyers think about their roles and tasks, rather by a set of metaphysical doctrines. ${ }^{128}$ Indeed, for Fuller, metaphysical doctrines were themselves best justified on pragmatic grounds. As he said in closing his contribution to a collection of essays entitled, My Philosophy of Law, "[w]e must have a good metaphysics before we can have a good politics. And a good metaphysics is one which gives form to life without stifling it." 129

\section{Technocratic instrumentalism: Lasswell and McDougal's "Policy Science"}

Frank and Fuller's shared philosophical assumptions can be seen even more clearly by setting them both in contrast to a quite different approach to legal reasoning advanced at the same time they were writing. In the early 1940s, two Yale professors wrote a now-famous article that has been said to "mark the clear beginning of the post-realist period" in American legal scholarship. ${ }^{130}$ In "Legal Education and Public Policy," Harold Lasswell, a political scientist, and Myres McDougal, a law professor, boldly put forth a vision of the lawyer's role in the world and the methods and skills he would need to serve it. ${ }^{131}$ Over the next several years, they taught these skills and methods, which they called "policy science," in a course at Yale law school. Although the views of McDougal and Lasswell depend on assumptions and goals similar to those we have seen in the work of Frank and Fuller, the vision of law and legal theory they offered differ dramatically from the views described above. ${ }^{132}$

Like many other legal theorists with legal-realist sympathies (including, as we have seen, Frank and Fuller), McDougal and Lasswell understood law in instrumental terms, as a tool designed to accomplish certain

127. FULLER, QUEST, supra note 42 , at 2.

128. It is for this reason that Fred Schauer suggests that we might charitably read Fuller as writing from an "internal point of view." See Frederick Schauer, Fuller's Internal Point of View, 13 LAW \& PHIL. 285, 302 (1994). For reasons stated elsewhere, I find that characterization unsatisfying. See Charles L. Barzun, The Forgotten Foundations of Hart and Sacks, 99 VA. L. REV. 1, 57-61 (2013); Charles L. Barzun, Inside-Out: Beyond the Internal-External Distinction in Legal Scholarship, 101 VA. L. REV. 1203 (2015).

129. Lon L. Fuller, My Philosophy of Law - Credos of Sixteen Scholars 125 (1941) (Reprint 1987).

130. DUXBURY, supra note 5, at 169 (quoting Robert Stevens, "Two Cheers for 1870: The American Law School," 5 PERSPECTIVES IN AM. HIST. 403 (1971)).

131. Harold D. Lasswell \& Myres S. McDougal, Legal Education and Public Policy: Professional Training in the Public Interest, 52 YALE L.J. 203 (1943).

132. DUXBURY, supra note 5 , at 168 . 
goals. ${ }^{133}$ They also stressed the need for law to look beyond traditional legal materials. They expressed frustration with earlier realist efforts to incorporate the social sciences because those realists had lacked a clear understanding of the purpose to which those social sciences needed to be put. ${ }^{134}$ Lasswell and McDougal lamented that although lawyers had recognized the need to evaluate legal doctrines and procedures according to how well they achieved social purposes, "there is little conscious, systematic effort to relate [those doctrines and procedures] clearly and consistently to the major problems of a society struggling to achieve democratic values." $\mid 35$

Here lies the first key difference between their approach and that of Frank and Fuller. Whereas those thinkers emphasized the inherent difficulty of knowing precisely what one's own values and motives were so that one had to discover them as one worked through a problem or reasoned through an issue-Lasswell and McDougal stressed that the modern lawyer must develop "goal-thinking," so that he could engage in effective "policymaking." This required having a "clear conception of goal," which meant that the student needed to "clarify his moral values (preferred events, social goals)." 136

For Lasswell and McDougal, "clarifying" moral values did not mean probing into their foundations. Here the contrast with Fuller is particularly striking. Fuller would later observe in a short 1950 essay that the question of "[h]ow far we should pursue ultimates" was dictated mostly by intellectual fashion. He then lamented that " $[t]$ he pressures of our present intellectual climate are toward truncating the inquiry at the earliest possible point," but he nevertheless insisted that he would resist that pressure and "push my inquiry a little farther toward the abyss than is customary." 137 Lasswell and McDougal, however, insisted that the process of clarifying values be distinguished from the effort to derive values, which was "a notorious blind alley." Such an endeavor, they explained, "quickly becomes a futile quest for a meaningless why, perpetually culminating in "some inevitably circular and infinitely regressive logical justification' for ambiguous preferences." 138 So rather than derive such values, Lasswell and McDougal stipulated them: "In our civilization, at least, representative values are power, respect, knowledge, income, and safety (including health)." ${ }^{\prime 39}$

133. See DUXBURY, supra note 5, at 171 (observing that although Lasswell and McDougal were critical of realists for their lack of clear objectives, they "applauded realist jurisprudence for the fact that it represented, in general; a pioneering attempt to integrate law with the social sciences").

134. Lasswell \& McDougal, supra note 131, at 204.

135. Id. at 205 .

136. Id. at 212 .

137. Fuller, On Teaching Law, supra note 113, at 36.

138. Id. at 213 (quoting McDougal, Fuller vs. the Realists, supra note 42, at 835 ) (emphasis in original).

139. Id. at 217. 
Once the lawyer had his policies or values in clear view, the next step was to determine the most efficient means of implementing them. Herein lies the other feature that distinguished Lasswell and McDougal's approach from what we have seen in both Frank and Fuller - their confidence in scientific methods. According Lasswell and McDougal, lawyers must know how to conduct "accurate calculation of probabilities, and adept application of knowledge of ways and means." The lawyer must learn "trend-thinking" and "scientific-thinking," which required him to "orient himself correctly in contemporary trends and future probabilities" in order to better predict possible outcomes. ${ }^{140}$ Thankfully, recent progress in the human sciences had made predicting human behavior easier. Thanks to "the rapid expansion of the social and psychological sciences," they explained, "the observing of human conduct has become progressively more technical and exhaustive." Indeed, social scientists had made the most progress in "the perfecting of method by which ancient speculations can be confirmed, modified or rejected." 141

The contrast drawn should now be clear. Whereas Frank and Fuller both stressed the impossibility of ever having complete consciousness of human motives and purposes, Lasswell and McDougal took awareness of one's goals or values to be the first step in the rational implementation of policy. Fuller himself drew the contrast between his own method and that envisioned by McDougal and Lasswell. For them, he explained, "the philosopher or legal reformer is supposed to determine what values are to be effectuated" while the rest is "a matter of technical implementation with which Professors McDougal and Lasswell have no direct concern and for which they assume no responsibility." ${ }^{142}$ Fuller thought this approach absurd, and he illustrated the point through the example of a game. One would never say, he insisted, "Let us first decide what kind of enjoyment we seek from our projected game. Then let us draw up rules for a game that will yield this form of enjoyment." Instead, when inventing a game "we shall have to start with ends vaguely perceived and held in suspension while we explore the problem of devising a workable system of play."143 In short, if Lasswell and McDougal saw lawyers and judges as "policymakers" or technocrats, Frank and Fuller each saw them as something like artists or craftsmen.

\section{ROMANTIC PRAGMATISM: A TRADITION?}

The ends to which courts have addressed themselves, the reasons and motives that have guided them, have often been vaguely felt, intuitively or almost intuitively apprehended, seldom explicitly

140. Id. at 213 .

141. Id. at 214.

142. Fuller, Philosophy at Mid-Century, supra note 111, at 479.

143. Id. 
avowed. There has been little of deliberate introspection, of dissection, of analysis, of philosophizing.

Benjamin Cardozo (1921) $)^{144}$

[I]n less guarded moment [judges] tell a different and more romantic story. They say that law is instinct rather than explicit in doctrine, that it can be identified only by special techniques best described impressionistically, even mysteriously. They say that judging is an art, not a science, that a good judge blends analogy, craft, political wisdom, and a sense of his role into an intuitive decision, that he "sees" law better than he can explain it, so his written opinion, however carefully reasoned, never captures his full insight.

\section{Ronald Dworkin (1986) ${ }^{145}$}

I have sought to identify in this Article a number of themes common to the work of Jerome Frank and Lon Fuller. In both we see the idea that people's perceptions of the world are fundamentally shaped by their emotions, motives, and purposes and that those emotions, motives and purposes often remain unconscious. Judges can decide cases justly if they attend to their own felt reactions the facts of the cases before them. When they do so, judges should try their best to articulate the reasons that they think justifies or supports their decisions. Both Frank and Fuller recognize, however, that such attempts at articulation are often only partially successful. Nevertheless, in spite of the incompleteness of such effortsindeed, because of its incompleteness - both thinkers maintain a faith that the Anglo-American method of case-by-case adjudication is a just method for resolving disputes and developing the law. The sort of practical reasoning adjudication requires, under this view, is one that requires judges to engage in a process of self-examination or introspection as to their true purposes and values.

This common set of views is what I call a romantic pragmatist understanding of adjudication and legal reasoning. The terms "pragmatism" and "romanticism" are both ones that are so commonly used that invoking them risks causing confusion or, worse, making vacuous claims. ${ }^{146}$ Some clarification of my use of those terms is therefore warranted. I will then raise two objections to this characterization.

144. Benjamin N. Cardozo, The Nature of the Judiclal Process 47 (1921)

145. RONALD DWORKIN, LAW'S EMPIRE 10 (1986).

146. The classic statement of this worry is Arthur O. Lovejoy, The Meaning of Romanticism for the Historian of Ideas, 2. J. HIST. OF IDEAS 257, 258 (1941) (arguing that the diversity of uses to which the term has been put "furnishes sufficient proof, if any were needed, that 'Romanticism' has no generally understood meaning and has therefore come to be useless as a verbal symbol"). See also CHARLES TAYLOR, SOURCES OF THE SELF (1989) ("The word [Romanticism] has a bewildering number of definitions; and some have even doubted that there is such a unified phenomenon, as against simply a conceptual muddle hidden in a single term.") (citing Lovejoy, id.). The same could be said of Pragmatism. 


\section{A. Romantic Pragmatism}

Pragmatism sometimes refers to a view about the nature of truth according to which what it means for some proposition to be true is not that it corresponds to some feature of the external world but rather that it "works" or has favorable practical consequences. ${ }^{147}$ But I mean it to refer more broadly to the view that experience supplies the proper test for assessing philosophical doctrines, whether metaphysical, ethical, or otherwise. Such an approach sometimes, but not always, entails the rejection of traditional philosophical dichotomies, such as those between reason and emotion, fact and value, mind and world. ${ }^{148}$

The concept of "experience" is, of course, somewhat vague and may invite more questions than it answers. ${ }^{149}$ Is it individual experience, or the collective experience of a community? ${ }^{150}$ More important for our purposes, what kinds of experience count as a basis for validation? Observations? Moral intuitions? Mystical feelings? ${ }^{151}$ Philosophical pragmatists differ on such issues.

Consider, for instance, two mid-century pragmatists, W. V. Quine and Morton White. Both philosophers famously rejected the analytic/synthetic distinction, which had been a foundational assumption of logical positivism, the dominant philosophical view at the time and one that privileged the methods of the natural sciences. ${ }^{152}$ But they interpreted the demands of pragmatic thinking in different ways. Quine is well known for insisting that in the sciences, "no statement is immune from revision," suggesting a fallibilism typical of pragmatists. ${ }^{153}$ But he still agreed with the logical positivists that observation through the senses was the only sort of experience that could validate philosophical knowledge. He therefore argued that traditional areas of philosophical inquiry, such as ethics and epistemology, should be "naturalized", that is, transformed into objects of empirical study using the methods of the natural sciences. ${ }^{154}$ White,

147. Stanford Encyclopedia of Philosophy, Pragmatism (Oct. 7, 2013) ("The core of pragmatism was the pragmatist maxim, a rule for clarifying the contents of hypotheses by tracing their 'practical consequences'. In the work of Peirce and James, the most influential application of the pragmatist maxim was to the concept of truth."), available at http://plato.stanford.edu/entries/pragmatism/.

148. See, e.g., id. ("All the pragmatists, but most of all Dewey, challenge the sharp dichotomy that other philosophers draw between theoretical beliefs and practical deliberations.").

149. See Cheryl MiSAK, The AMERICAN Pragmatists xi (2013) (observing that "the nature of the requisite connection between beliefs and experience is a complex matter for the pragmatists").

150. See id. at 37 (explaining that Pierce "thought that truth was a matter for the community of inquirers--not for this or that individual inquirer"); id. at 60 (". . James adds to Peirce that we must pay attention to the significance that each of us places upon our own particular actions.").

151. See id. at 68 ("Mystical experience, James argues, is the province of the subconscious and is as telling for the perceiver as is the experience of ordinary, mundane consciousness.").

152. W. V. Quine, Two Dogmas of Empiricism, 60 PHIL. REV. 20 (1951); Morton White, The Analytic and the Synthetic: An Untenable Dualism, in JOHN DEWEY: PHILOSOPHER OF SCIENCE AND FREEDOM (I950).

153. Id. at 40. See Stanford Encyclopedia, supra note 147 (observing that pragmatists "tended to share a distinctive epistemological outlook, a fallibilist anti-Cartesian approach to the norms that govern inquiry").

154. W. V. Quine, Epistemology Naturalized, in ONTOLOGICAL RELATIVITY AND OTHER ESSAYS 
meanwhile, insisted that one's moral intuitions properly count as part of how we validate our beliefs, including ethical and metaphysical ones. He thus had more faith than did Quine in the value of philosophical inquiry in such traditional areas as ethics, religion, aesthetics, and law. ${ }^{155}$

This latter sort of pragmatism, which includes emotional reactions and intuitions as the sort of "experience" that can validate beliefs and which is associated with William James, Morton White, and others, is the one I dub "romantic." I mean that term not to describe the quality that contrasts with "realist" or "rationalist" views, but rather to refer to a set of ideas connected to the particular movement in art and literature that began in the late eighteenth and early nineteenth centuries. In particular, I intend the term to refer to three features commonly associated with that movement. The first and most obvious is the idea that the human self has a certain inner depth full of emotions and intuitions and that attending to those emotions can yield genuine aesthetic and ethical insight. ${ }^{156}$ The second is the view that such feelings are often stimulated by particular and concrete experiences and that generalizing from such concrete experiences is always difficult, making our attempts to articulate our judgments about them always partial and imperfect. ${ }^{157}$ The third and final feature is the insistence upon the foundational role played by the first two features. If our evaluative judgments are properly understood as efforts to articulate genuine moral insights derived from our responses to concrete experience,

\section{(1969).}

155. See MORTON White, TOWARd REUNion in Philosophy 20 (1956) ("Once logicians and epistemologists begin to speak of justifying conceptual frameworks by reference to considerations of expediency, as some do, and once others begin to counter by appealing to intuition or conscience, as they do, we can see that we are entering a subject which might well profit from the two thousand years or so of moral philosophy in which very similar questions have been discussed."). See also MORTON White, A PHILOSOPHY OF CULTURE xi (2002) ("I also came to believe that ethics may be viewed as empirical if one includes feelings of moral obligation as well as sensory experiences in the pool or flux into which the ethical believer worked a manageable structure (to use a James-like figure that Quine had once used when characterizing the purpose of science)."); id. at 154 ("Quine differentiates more sharply than I do between an observation sentence like 'that's a rabbit' and the sentence 'that ought not to be done' or 'that's outrageous,' its counterparts in my view of the confirmation of ethical beliefs. That difference between us reflects my inclination to emphasize the similarity between ethical and scientific thinking and Quine's different inclination.").

156. TAYLOR, supra note 146, at 368 ("This notion of an inner voice or impulse, the idea that we find the truth within us, and in particular in our feelings--these were the crucial justifiying concepts of the Romantic rebellion in its various forms."); Harold Bloom, ed., Romanticism and Consciousness: Essays in Criticism 1 (1970) ("Subjectivity or self-consciousness is the salient problem of Romanticism, at least for modern readers, who tend to station themselves in regard to the Romantics depending on how relevant or adequate they judge the dialectic of consciousness and imagination to be.").

157. Robert langbaum, The Poetry of Experience: The Dramatic Monologue in MODERN LITERARY TRADITION 35 (1957) (explaining that the essence of romanticism is the "doctrine of experience," according to which "the imaginative apprehension gained through immediate experience is primary and certain, whereas the analytic reflection that follows is secondary and problematical"); TAYLOR, supra note 146, at 390 ("The sense of depth in inner space is bound up with the sense that we can move into it and bring things to the fore. This we do when we articulate. The inescapable feeling of depth comes from the realization that whatever we bring up, there is always more down there. Depth lies in there being always, inescapably, something beyond our articulative power."). 
then such evaluations are, in some sense, empirical or descriptive ones. Such a capacity thus provides a firmer ground for moral and aesthetic judgments-a ground that used to be provided by larger metaphysical or theological frameworks. ${ }^{158}$

The romantic pragmatist about ethics or practical reasoning, then, is a pragmatist who believes that one's moral beliefs, like one's scientific beliefs, should always be open to revision and subject to the test of experience. But she is also a romantic who believes that one's intuitions or emotional responses contain real moral insight. She is thus the sort of pragmatist who, when reasoning about ethical matters, treats such intuitions or internal reactions as part of the experience that tests the adequacy of her beliefs.

It is not hard to see, then, why Frank and Fuller may plausibly be described as romantic pragmatists when it comes to adjudication and legal reasoning. Both of them thought legal rules should be assessed by how well they achieve the purposes for which they exist. Frank encouraged judges to reflect on their own emotional responses in order to ensure that they are not beholden to biases and prejudices ${ }^{159}$; he praised the "scientific spirit," which welcomes uncertainty and the questioning of settled dogma ${ }^{160}$; he envisioned the judge as an artist who can never quite articulate the true grounds for decision. ${ }^{161}$ Similarly, Fuller defended legal fictions on the ground that they provide just results even when judges cannot articulate a satisfying legal justification ${ }^{162}$; he insisted that there are purposes latent in the law that judges can intuitively discern ${ }^{163}$; and (for these reasons) he envisioned the judge's role as part creation, part discovery. ${ }^{164}$ Finally, both thinkers argued that judicial decisionmaking can be just even when there are not clear rules governing a case precisely because judges may be guided by introspective inquiry. That is why they are both romantic pragmatists about law and adjudication.

\section{B. Historical Implications}

Understanding Frank and Fuller as romantic pragmatists is useful for both historical and philosophical reasons. As an historical matter, identifying the intellectual connections between Frank and Fuller provides

158. TAYLOR, supra 146, at 380 ("The old order based on the ontic logos was no longer acceptable.... What replaced the interlocking order was the Romantic notion of a purpose or life coursing through nature."); Langbaum, supra note ., at 26 ("[The Romanticist] discovers through experience the empiric ground for values. He does this by giving himself so completely to each object that the object is allowed to generate its own laws, creating the values compatible with its full existence... The romanticist is thus always in the process of formulating values, although he never arrives at a final formulation.").

159. See supra, p. 134.

160. See supra, p. 135.

161. See supra, p. 146.

162. See supra, p. 135.

163. See supra, pp. 149-53.

164. See supra, p. 151. 
a new perspective on mid-twentieth-century legal thought. The romantic/technocratic distinction drawn here cuts across the traditional realism/process theory dichotomy. During both periods one finds both strands of legal pragmatism on offer.

The interpretation here offered expands upon a revisionist account of twentieth-century legal theory. Neil Duxbury has argued that, contrary to the conventional wisdom at the time, legal-process theory was less a "response" to legal realism than it was the manifestation of an attitude about law-in particular, a faith in its immanent rationality-that had begun long before the 1940s and has endured long past it. ${ }^{165}$ Elsewhere I have argued that in certain ways legal process theory was indeed an effort to respond to certain aspects of legal realism. ${ }^{166}$ It is nevertheless true that the continuity we find in Fuller's and Frank's thought over more than two decades in some ways confirms Duxbury's thesis.

This Article is meant to build upon this revisionist account in two ways. First, it brings out the way in which (perhaps ironically) the "rationalist" tradition in general depends on the romantic faith in the epistemic value of intuitions - and the introspection necessary to discern them - for the purposes of judicial decisionmaking. As the quotations that introduced this Part indicate, this idea both preceded the work of Frank and Fuller and has continued long after it.

The second way it builds upon Duxbury's account is by clarifying that the romantic faith in introspection does not entail the endorsement of law's immanent rationality (or vice versa). Duxbury does not group Jerome Frank along with Roscoe Pound, Benjamin Cardozo, Henry Hart, Ronald Dworkin, and other defenders of law's rationality. ${ }^{167}$ Now we can see why: Although Frank shared with these others the idea that one's intuitions about particular cases serve as a genuine ethical guide, he differed from them and from Fuller in his relative lack of confidence in judges' ability to generalize from those intuitions. Frank doubted the existence or at least the utility of general principles of natural law, and he welcomed the diversity, rather than uniformity, of judicial judgments.

Under this view, then, part of what distinguishes Frank from the rationalist tradition Duxbury describes is not a denial of the power of judges to decide particular cases in a just way. Rather, it is a skepticism that the morally salient facts which make certain judicial outcomes just ones are universalizable. The difference between Frank, on the one hand, and Fuller and others in the "rationalist" tradition, on the other, is not

165. DUXBURY, supra note 5, at 205-06.

166. Barzun, Hart \& Sacks, supra note 128 , at 47-48.

167. Each of those theorists are discussed in Duxbury's chapter entitled, "Finding Faith in Reason." DUXBURY, supra note 5, at 205-99. Of course, part of the reason for the omission of Frank is that, as I've argued here and elsewhere, scholars have misunderstood Frank. But part of the reason is that the relevant connection between Frank and Fuller is not one about the existence of reason in the law, at least not as "reason" is conventionally understood. 
about the need for judges to introspect-they all agreed they should. The difference is about the generality of the truths thereby discovered. In that way, the difference maps to analogous differences among the original romantic critics and artists. ${ }^{168}$

\section{Philosophical Implications}

Have we simply returned, then, to the age-old and hackneyed question of whether law is an art or a science? That is how Dworkin frames the issue in the quotation introducing this Part. Though sympathetic to the romantic account, Dworkin goes on to dismiss it as "too unstructured, too content with the mysteries it savors, to count as a developed theory of what legal argument is about." He thus insists on the need to "throw discipline over the idea of law as craft." 169

The art/science distinction does point in the right direction. But that framing of the issue is conclusory insofar as it assumes particular understandings of art and science which are themselves controversial. Romanticism is often contrasted with both "classical" and "modern" forms of music, art, or poetry, and yet those sensibilities have just as much claim to the notion of counting as "art" as does the romantic one. ${ }^{170}$ The same is true of science, the nature of which is still a question of lively controversy. How are to we understand, for instance, what scientists actually do? Are they engaged in a primarily intellectual or technological enterprise? ${ }^{171}$ Do they engage in acts of genuine discovery? If so, what is the nature of that process? Is there a so-called "logic of discovery" that can be formalized in terms analogous to the "logic of justification?" Or do scientific discoveries result from a "flash of insight" that is itself resistant to systematization? ${ }^{172}$

Analogous questions can be asked about law. In what sense, or under what conditions, can legal methods, sources, and values constitute a

168. TAYLOR, supra note 146, at 369 (observing of the romantics, that "[s]ometimes the voice or impulse is seen as particular to the person himself; it is the voice of one's self" and that "[s]ometimes it is also seen as the impulse in us of nature, as the larger order in which we are set")

169. Id. at 10-11.

170. See FRANK, COURTS ON TRIAL, supra note 71 , at $394-95$ (criticizing a legal scholar's suggestion that in both art and law "rhythm or pattern has the value of regulating," which Frank characterizes as a "classical" view of both art and law).

171. See Alfred Nordmann, Review of Lena Soler et al, "Science after the Practice Turn in the Philosophy, History, and Social Studies of Science," NOTRE DAME PHIL. REVS. (June, 2015) (concluding his review with the observation that "[w]hat is at stake with all these questions is not what scientists do but whether their practice is intellectual or technological").

172. See Thomas Nickles, Discovery, in A Companion to the Philosophy of Science (W. H. Newton-Smith ed., 2000) (including among "central, overlapping clusters of questions that philosophers and methodologists raise about discovery" such questions as "[i]s the manner in which scientists make discoveries at all similar to the way in which they test them? Is this justificatory 'checkout' procedure really part of the larger discovery process rather than distinct from it? Can discoveries be explained rationally, or do they always contain irrational or nonrational elements, such as inspiration or blind luck?"). For a discussion of the distinction between the "context of discovery" and the "context of justification" as drawn by legal theorists, with particular application to European legal theory, see Stef Feyen, Towards Systematic Realism (working title), diss. doct. Leuven University 2016, Ch. 2, forthcoming. 
source of genuine discovery of truths about the world? Or, conversely, to what extent are they instead properly understood as merely practical tools for the implementing antecedently fixed ends or goals - irrespective of whether those goals are understood to be the outcome of some "rational" process or merely to be the reflection of some individual or group's arbitrary will. In other words, the question is whether there is a role of genuine discovery in legal practice analogous to what some find in scientific practice.

What is at issue here is not the traditional question about the "nature of law" that has occupied legal philosophers for the last several decades. That question, as typically framed, is whether law depends exclusively on "social facts" (as Hart and other positivists argue) or instead depends on a combination of social facts and values (as Dworkin and anti-positivists argue). ${ }^{173}$ That is a metaphysical question about what determines the content of law. ${ }^{174}$ The question here is an epistemological one: Whatever facts make some rules or principles qualify as valid law, is it possible to learn genuine truths about the world by reflecting on the various methods, sources, and values that constitute legal practice as a whole? And if so, what assumptions does an affirmative answer depend on? In other words, it asks whether law qualifies as an intellectual discipline or is instead simply a practical instrument of social control (and, possibly, moral guidance).

As it turns out, both Fuller and Frank were very interested in the ways in which legal concepts and practices had had an intellectual influence on other sciences and disciplines. ${ }^{175}$ True, they each tended to focus on different aspects of the legal process. Frank was more concerned with trial processes and the evaluation of witness testimony, whereas Fuller was more interested in the processes of appellate adjudication, particularly where the relevant rules did not dictate a clear outcome. Yet both saw an important connection between the methods and procedures of legal practice and the ends towards which the law should aim, so that one could learn something about the latter by studying the former. This Article has suggested that they could only maintain such a faith in the possibility of genuine discovery of truth through the examination of legal practices because they were romantic pragmatists, that is, because they believed in

173. H.L.A. HART, THE CONCEPT OF LAW (3d 2011); DWORKIN, supra note 145.

174. Scott Hershovitz, The End of Jurisprudence, 124 YALE L.J. 1160, 1167 (2015) ("All three views [in the Hart-Dworkin debate] offer an answer to the same question. The question is what facts determine the content of the law. In different ways, all three views purport to provide a metaphysical account of our legal rights, obligations, privileges, and powers.").

175. Fuller, Fictions III, supra note 15 at 907 ("It should be recalled that the courts were pioneers not only in the field of the social sciences, but perhaps in the field of science generally. If we define science as the conscious generalization of experience, then the law was the first of the sciences."); Jerome Frank, A Conflict with Oblivion: Some Observations on the Founders of Legal Pragmatism, 9 RUTGERS L. REV. 425 (1954) (noting that law has had an influence on scientific thought with respect to such concepts as "fact," "cause," "responsibility," and "average" and observing that "[t]he "logic of discovery' (or of 'invention') has its roots in lawyers' techniques"). 
the epistemic value of "imagination, intuition, insight."176

\section{CONCLUSION}

Jerome Frank and Lon Fuller are typically placed on opposite sides of most of the dichotomies drawn in legal theory, whether by legal historians or philosophers. But along one dimension-whether and in what sense law may properly be seen as an intellectual practice-they were very much, as we might say today, on the same page. That is because they shared a common philosophical outlook according to which the human mind constructs knowledge by imposing its (sometimes unconscious) purposes on the world, rather than by merely passively observing it. The consequence of this view was a belief in the interdependencies between means and ends, theory and practice, reason and emotion, and between factual and evaluative judgments. Some legal scholars in their day shared this outlook. But even many who adopted an instrumentalist understanding of law rejected it. No doubt one could find a similar split today. The failure of the traditional categories to track the lines of this debate suggests that those categories are leaving out something important.

176. FRANK, MODERN MIND, supra note 18 , at 181. 